DOI https://doi.org/10.36059/978-966-397-111-7/5-25

\title{
FEATURES OF MEMORIAL POLICY IN CRIMEA IN THE CONTEXT OF RUSSIAN ANNEXATION
}

\section{Horiunova Y.}

\section{INTRODUCTION}

The Russian Federation is waging a hybrid war on various fronts. The Kremlin uses almost the entire complex of its means Against Ukraine - from real military hostilities in the eastern part of the country, although under slogans "we are not there", to a powerful anti-Ukrainian information campaign. Wars of the XXI century are already far from the traditional perception of an armed conflict, because they ceased to be solely military actions. "It is necessary to take into account the sociocultural, techno-economic and geopolitical dimensions of a war," a hybrid war scholar, F. Hoffman, said ${ }^{1}$.

One of the key features of the Russian hybrid war against Ukraine is the Kremlin's memorial policy, which helped the Russian authorities to justify "the return of Crimea to their native harbor." Accordingly, statements about the Crimea as an integral part of Russia continually appear in program speeches of the Russian President Vladimir Putin. Allegedly, these ancient ties of the peninsula with the "Russian world" start from the baptism of Volodymyr in Korsun (Chersonesus).

The memorial policy and the formation of a corresponding cultural space of the Crimea promote the implementation of the Kremlin's strategy. This strategy is filled with Russian symbols, ranging from monuments and ending with names of streets. This space has been forming over several centuries along with the myths about the "ancestral affiliation" of Crimea and Sevastopol to Russia.

During Soviet times, Russian imperial symbols disappear from the Crimea. Monuments to tsars were destroyed and replaced with mass renaming of settlements and streets in honor of Soviet leaders. During the time of independent Ukraine, the symbolic field of the Crimea has not

${ }^{1}$ Hoffman F. G. Hybrid Warfare and Challenges. Joint Force Quartelly (JFQ). Issue 52. Forth Quarter. 2009. P. 36 
changed much, because the Ukrainian authorities did not pay close attention to the implementation of the humanitarian policy on the peninsula. Accordingly, the Russian-Soviet cultural heritage prevailed, which greatly facilitated the annexation of the Crimea.

After 2014, Russia has been actively implementing new humanitarian vectors by distributing cultural symbols that are in line with its current memorial policy, taking into account Crimea's specifics. New monuments that appeared in the Crimea after the Russian annexation completely coincide with the tasks of demarcation of the Crimean symbolic field in accordance with the modern Russian historical tradition - a combination of imperial and Soviet principles with an emphasis on a militaristic format.

\section{Russian-Soviet symbolism preceding the annexation of the Crimea}

When the Crimea was within the Russian Empire, and then within the Russian Soviet Socialist Republic (RSFSR), the corresponding cultural and symbolic space of the peninsula was formed. It combined Russian and Soviet cultural codes. Despite the fact that since 1954 the Crimean oblast was part of the Ukrainian Soviet Socialist Republic, Ukrainian cultural symbols were presented very limitedly, which gave Russia additional opportunities to insist on its rights to own the Crimea.

The symbolic space of the city of Simferopol demonstrates certain features of the cultural and symbolic space of Crimea right before the Russian annexation. For example, as of 2014 out of the city's eight squares half is related to the Soviet past. These are the Square of Lenin (the main square of the city), the Soviet Square, the Square of the Soviet Constitution, Kuibyshev Square (in honor of a Soviet leader). The names of other two are neutral - Vokzalna and Sportyvna, one is associated with Russia - Moscow Square. Another square in the city center has the name of twice Hero of the Soviet Union, Amet-Khan Sultan - a Crimean Tatar pilot, hero of the Great Patriotic War.

We have the similar situation with the names of the streets of Simferopol. As of 2014 there were more than 700 streets in the city (excluding alleys and passages). All central streets of the Crimean capital kept Soviet names: Lenin (besides the street there is a boulevard), Kirov, Marx and other revolutionary figures. The buildings 
of the republican authorities are located on the streets with the following names: the Verkhovna Rada of the Autonomous Republic of Crimea (ARC) on Karl Marx Street, and the building of the Council of Ministers - on Lenin Street.

In total, 46 streets of Simferopol were named in honor of the participants in the revolution of 1917, in the civil war and of the Soviet leaders, 20 of which are not related to the city at all. Several streets were named in honor of revolutionary figures who were directly related to the bloody executions - Bela Kun, Mate Zalka, Dzerzhynsky. For example, Bela Kun was the initiator of mass repressions in the Crimea in the 1920-1921.

The names of more than 20 Simferopol streets are connected with the revolutionary events of 1917 and the Great Patriotic War. For example, The 60th anniversary of the October Street (in honor of the October Revolution of the Bolsheviks in 1917), the Heroes of Stalingrad Street (in honor of the Battle of Stalingrad in the winter of 1942-1943), the Red Army and Red Flag Street (in honor of the Red Army during the Civil War in Russia).

But most of the streets were named after heroes of the Great Patriotic War and Crimean underground resistance -65 streets, only 10 out which are not related to the Crimea (to a large extent, they are members of the "Young Guard" - an underground youth organization in Krasnodon USSR in 1942-1943).

The number of streets named in honor of Russian cultural figures is 34 (20 of them have no relation to the Crimea); eight are named in honor of historical figures (five of them are not related to the Crimea); seven were named after representatives of Soviet culture.

Following the returning and settlement of the Crimean Tatars in Simferopol some streets have been named after the Crimean Tatar heroes of war and those who fought for the rights of these deported people. There are about 30 of such streets, but all except the Square of Amet-Khan Sultan were located in the Crimean Tatar districts of the city.

As for Ukrainian cultural or historical leaders, only five streets bear their names - Mykhailo Kotsiubynsky, Lesia Ukrainka, Hryhorii Petrovsky, Ivan Franko and Taras Shevchenko. Everyone except Petrovsky are Ukrainian writers and poets. 
Following the collapse of the USSR, the process of decomunization and de-Sovietization unfolded in Crimea, but it was very short and touched only six streets. In 1991, the Voroshilov's Street (the Russian revolutionary and Soviet statesman) was renamed to Bitak Street. The Parkhomenko Street (the revolutionary figure and the participant of the Civil War) - to the Karaim Street (in honor of one of the peoples who live in the Crimea). The Quay of the 60th Anniversary of October Street became the Quay of Ismail Gasprynsky, a prominent Crimean Tatar enlightener.

A new wave of renaming has begun in 2008 by the initiative of Russian organizations of the Crimea, who managed to secure the returning of the pre-revolutionary names to three streets from the local authorities. Thus, instead of the streets in honor of the German revolutionaries Karl Liebknecht and Rosa Luxemburg, the Dovhorukivska Street appeared on the map of Simferopol (in honor of Russian historical figures) and the October Street became the Petropavlivska Street.

Historical monuments carry a special semantic load. Although, there are not many on them in Simferopol, but there are already two to the "leader of the world's proletariat". One stands in the center of the city - on the main square, where ceremonies and celebrations take place; the other one was meeting the guests of the peninsula near the railway station. That is, both monuments are located in the iconic places for the city. The smallscale attempts by the public to remove these monuments caused a fierce opposition from local Communists.

A bust of Mykhailo Frunze, a Soviet figure who was involved in mass terror in the Crimea, was moved from the main building of the V.I. Vernadsky Tavrida National University (TNU) to another university campus only in 2013. But these actions caused dissatisfaction of some part of university instructors. A monument to Volodymyr Vernadsky, who headed the university in 1920, was erected at the entrance to the main building of the TNU.

Also a monument to Pavlo Dybenko, a revolutionary and statesman of Ukrainian origin, remained in the city on the square named after him. And the bust of Mykola Kyrychenko, the first secretary of the Crimean Regional Committee of the Communist Party of the Soviet Union. A very interesting building in the city center is called "A shot in the back". This 
is a monument to the "victims of Ukrainian nationalists", that is, the fighters of the OUN-UPA - the Ukrainian Insurgent Army. It was erected and financed by the Crimean Communists in 2007.

According to the first secretary of the Crimean Republican Committee of the Communist Party of Ukraine Leonid Hrach, "about four thousand Crimeans, the representatives of peaceful occupations, died from the hands of Fascist supporters, in Western Ukraine""2.

The installation of this monument triggered a tough reaction from representatives of the Ukrainian right-wing parties. So, the leader of the People's Movement of Ukraine Leonid Pilunsky called these actions of the Communists a provocation by the Communists, who were executioners, since tens of thousands of people were murdered by them in the 1920s of the last century ${ }^{3}$.

Regarding Russia's historical or cultural heritage, it is represented by the Dovgorukov Obelisk which was erected in honor of the victory over the Turkish troops (1842), monuments to Alexander Suvorov, Alexander Pushkin, and Petro Tchaikovsky.

The Ukrainian cultural heritage in Simferopol was represented by the bust of Taras Shevchenko at the entrance to the park bearing his name, and to General Petro Hryhorenko, who fought for the rights of the Crimean Tatars. In other cities of Crimea monuments to the Ukrainian Kobzar ("Bard" in the Ukrainian culture and literature) were also erected in Sevastopol, Yalta, and Yevpatoria. The monument to the Ukrainian poet Lesia Ukrainka was established in Yalta in 1971.

After the rehabilitation and mass return of the Crimean Tatar people to the Crimea, the memorials dedicated to the victims of deportation appeared on the peninsula. One of them is near the Botanical Garden of the V. Vernadsky Tavrida National University, the other is on the territory of the Crimean Engineering and Pedagogical University (KIPU).

Among of the most important memorials for Simferopol were the monuments in honor of the Victory in the Great Patriotic War (so called

${ }^{2}$ Коммунисты открыли в Крыму памятник «жертвам ОУН-УПА». УНIAH. 14.09.2007. URL: https://www.unian.net/common/64616-kommunistyi-otkryili-v-kryimu-pamyatnik-jertvam-oun-upa.html

${ }^{3}$ Симоненко открыл в Симферополе памятник жертвам ОУН-УПА. Корреспондент. 14.09.2007. URL: https://korrespondent.net/ukraine/events/207397-simonenko-otkryl-v-simferopole-pamyatnik-zhertvamoun-upa 
the events of the Second World in the Crimea following the USSR and Russia). First of all, these were the traditional Soviet-era memorials "The Eternal Flame" memorable boards. In 2010, a monument to the Separate Maritime Army was opened in Crimea, which liberated the Crimea from the Nazis.

A lot of memorable signs in honor of the Great Patriotic War remained throughout the Crimea in the form of monuments or military equipment mounted on a pedestal (tanks, airplanes, etc.), and obelisks with a red star. The largest number of them is in the heroic cities of Kerch and Sevastopol, with the similar memorials.

This kind of cultural and symbolic space was in the Crimea on the brink of the annexation, which created a mental field for the real occupation. The sociological surveys conducted in the Crimea before the annexation capture the domination of the Russian cultural tradition on the peninsula.

According to a poll conducted by the Razumkov Center in the Crimea in 2008, 55.5\% of respondents identified themselves with the Russian cultural tradition, $14.6 \%$ - with the Soviet, $8.8 \%$ - with the Ukrainian, and $8.3 \%$ - with the Crimean Tatar. The corresponding absolute majority of the Crimeans had a Russian-Soviet identity five years before the annexation of the peninsula, which became the basis for the implementation of the concept of the "Russian world" and the "protection" of Russian-speaking citizens in the Crimea. In the whole Ukraine, another tendency prevailed, $57.9 \%$ of respondents attributed themselves to the Ukrainian cultural tradition ${ }^{4}$.

It should be noted that such sentiments prevailed not only among middle-aged and elderly people, but even among young people. According to the polls of the Crimean student youth that was systematically conducted during 2007-2012, 35\% of young people considered the "October Revolution of 1917" as a positive event in history, $21 \%$ considered its consequences as negative, and $44 \%$ did not have an answer".

\footnotetext{
${ }^{4}$ АР Крим: люди, проблеми, перспективи. Національна безпека та оборона. 2010. № 10. С. 3-72.

${ }^{5}$ Хриенко Т.В. Молодежь Крыма о полытике и политиках (опыт социологических исследований) : монография. Симферополь, 2013. С. 92.
} 
Majority of student respondents $(50.5 \%)$ believed that there was no historical need for liquidation of the USSR (2012 poll). Based on such considerations of the Crimean students, the answer to the question if there is a need for the revival of the Soviet Union as an updated federation (1991 referendum type) is not surprising: $61.5 \%$ of students supported the restoration of the USSR.

The domination of the Russian-Soviet mentality explains the attitude of young Crimeans to Soviet monuments - the vast majority (83.5\%) were strongly against the demise of such monuments and condemned the corresponding actions in the Baltic countries (79\%). A provocative monument "A shot in the back" was supported by $43 \%$ of respondents, against were $24 \%$, and a third was not able to answer the question ${ }^{6}$.

The Russian historical tradition prevailed in the answers to questions about the Soviet history. Thus, almost $70 \%$ of the surveyed Crimean students considered the Soviet-German war as a "liberation war of the Soviet people against the Nazi invaders" and only $19 \%$ perceived it as a war of "the Fascist Germany and the USSR for spheres of influence in the world." Therefore, an absolute majority of Crimean students (84\%) did not see problems in decorating cities with the Soviet red flags and celebration of the Victory Day on May 9th. The Russian mythology about the Crimean Tatars as traitors and the limitation of their symbolic space is explained by the fact that almost $40 \%$ of young respondents supported Stalin's decision to deport the people.

Thus, the Crimea's existence in the Russian-Soviet cultural-symbolic, and accordingly, the mental sphere, greatly facilitated the annexation of the peninsula by the Russian Federation in the spring of 2014.

\section{The Right to the historical memory of Ukrainians and Crimean Tatars on the peninsula after the annexation}

Prior to the annexation of the Crimea by the Russian Federation, Ukrainians together with the Crimean Tatars were a minority. According to the 2001 census, over two million people lived in the Crimea, 58.5\% of which were Russians, $24.4 \%$ were Ukrainians and $12.1 \%$ were Crimean Tatars. That is, representatives of the title nation of the Ukrainian state on

6 Хриенко Т.В. Молодежь Крыма о полытике и политиках (опыт социологических исследований) : монография. Симферополь, 2013. С. 127. 
the peninsula were representatives of the minority, which significantly influenced the implementation of the memorial policy in the Crimea.

Monuments to the Ukrainian poet Taras Shevchenko have become the central venue for Ukrainian events in various cities of the Crimea. It is worth mentioning that unlike in Sevastopol, Yalta or Evpatoria, where large monuments of the Kobzar were installed, in Simferopol, the capital of the Crimea, only the Kobzar's bust was installed in 1997 which was a gift to the city from the city of Lviv. Traditionally, this was the place where representatives of the Crimean officials laid flowers on the Independence Day of Ukraine (August 24), on the Day of Unity (January 22), on the Constitution Day of Ukraine (June 28) and on the birthday of Taras Shevchenko (March 9). However, the first persons of Crimea were far from always present at these events. For example, on March 9, 2013, at the celebrations there was no speaker of the Crimean parliament Volodymyr Konstantynov or the head of the Crimean government Anatoliy Mohyliov. Even the mayor of the Crimean capital, Victor Ageiev, wasn't present there. Only the Permanent Representative of the President of Ukraine to the Autonomous Republic of Crimea, Viktor Plakida and the deputies of the Crimean Prime Minister Aziz Abdullaiev and Olga Udovina came to commemorate the memory of the Kobzar.

In addition, it was very difficult in Crimea to hold events dedicated to commemorating the soldiers of the Ukrainian Insurgent Army (UPA). Since there were no memorable signs in Crimea, representatives of Ukrainian organizations brought flowers to the bust of the Kobzar in Simferopol. But their actions were hampered by representatives of various pro-Russian parties and organizations, the local Russian Cossacks and the Crimean Communists.

During the Russian occupation of the peninsula, the monument to the Kobzar has become the place of the Ukrainian resistance to the Russian aggression. Thus, on March 9, 2014, when the peninsula was de facto occupied by the Russians in the guise of "the little green men," a rally in support of Ukraine was held near the Shevchenko bust, where several thousands of people tried to resist the aggression peacefully and stressed that Crimea is the integral part of Ukraine. A similar rally took place on March 9 in Sevastopol near the monument to Shevchenko. However, the 
representatives of pro-Russian structures tried to disrupt it and resorted to outright provocations.

After the official date of the annexation of Crimea, the monuments to the Kobzar have become a symbol of Ukrainian national identity and a center of public resistance to the occupation. Flowers appeared there not only on the birthday of the Kobzar, but also on the Day of Constitution or Independence of Ukraine. But the Crimeans were forced to do it under the supervision of the local police and security forces. Sometimes the Crimeans had no choice other than bringing flowers at night, as it was on October 14, 2015, when the Day of the Defender of the Fatherland has become the national remeberance day in Ukraine. In the morning, the Russian police surrounded the monument, and representatives of the city services quickly cleaned the bouquets with blue and yellow symbols.

In 2016, webcams were installed near the bust, therefore, all who come to the monument automatically fall under the supervision of the Russian special services as unreliable. Many Ukrainians were forced to leave the peninsula because of the pressure on them from the Russian occupation authorities to save their lives.

On March 9, 2014, the last gathering took place near the monument to the Kobzar in Simferopol, because in March 2015 the Crimean Ukrainians were forbidden from honoring the memory of the poet near his bust. Instead, they were offered to hold the event in another place - in the city park. A few dozen of people walked wearing embroidery shirts and under the Ukrainian flag. But its organizers and participants were detained by the local police for "violating the established procedure for organizing or holding a rally", that is, for the use of the Ukrainian symbols. All detained activists were sentenced by the Russian court in Simferopol to pay fines.

Since 2016, the Russian authorities have been involving the controlled "Ukrainian community of the Crimea" in the celebrations on March 9, whose representatives in the national clothes played roles laying flowers to the Kobzar's bust and reading his verses. The Crimeans, who came independently to the monument, at first were not even allowed to approach. Later they were given the permission to put the bouquets, but quickly and one by one being at the gunpoint of police, cameras and special services. 
In 2017, activists of the Ukrainian Cultural Center (UCC) intended to hold a public event to conduct a memorial near the Shevchenko monument. This organization has emerged after the Crimean occupation by Russia and emphasized its exclusively cultural activities and the preservation of the Ukrainian culture in the Crimea. However, the Russian authorities denied the UCC's request, referring to mistakes in completing the application form for the event.

The official celebrations near the Kobzar in Simferopol in March 2017 were conducted by the Ukrainian community of Crimea which was controlled by the Russian authorities, along with representatives of the Russian and Belarusian communities. These groups emphasized the Slavic cultural affiliation of the Ukrainian poet in their speeches. "Taras $\mathrm{H}$. Shevchenko is an outstanding person for the entire Slavic world, who made an invaluable contribution to art. He taught people to live together under peaceful skies, without bloody wars, and we must keep that in mind," said the head of the Ukrainian community of Crimea, Oleh Usyk. ${ }^{7}$

In other regions of the peninsula there are no official events, nor any significant restrictions on the laying of flowers to the monuments of Shevchenko. But the majority of the Crimean Ukrainians try to spend memorable days indoors by reading poetry.

In 2019, the occupant authorities of the peninsula allowed to hold a rally on March 9 near the Simferopol Kobzar to the pro-Russian organizations that came with the Russian flags and called Shevchenko a "Russian writer." After that, the Crimean Ukrainians finally managed to put flowers to the bust, read poems and perform some Ukrainian songs. ${ }^{8}$

Since the monuments to Shevchenko became centers of gravitation of the peninsula's pro-Ukrainian forces right during the annexation of The Crimea, the Russian authorities have been trying to restrict access to them and, through the use of controlled organizations, to promote their own version of the history of "the one people and Slavic brotherhood".

The Russian authorities of the Crimea demonstrate similar attitude towards the historical memory of the Crimean Tatars and try to impose on them only official events, where the most tragic date in the history of the

${ }^{7}$ Память украинского поэта Тараса Шевченко почтили чтением его стихов в Крыму. РИА Крым. 09.03.2017. URL: https://crimea.ria.ru/society/20170309/1109425136.html

${ }^{8}$ От митинга до подполья: как в Крыму омечают день рождения Шевченко. Крым. Реалии. 09.03.2019. URL: https://ru.krymr.com/a/photo/29082441.html 
Crimean Tatar people, the deportation, is interpreted in a completely different way.

On May 18, 1944, the mass deportation of the Crimean Tatars began and lasted until May 20. More than 32 thousand servicemen of the People's Commissariat of Internal Affairs (NKVD) were involved in the special operation against the Crimean Tatars 9 .

According to the archival data, during the special operation 18,686 "persons of Tatar nationality" were evicted from Crimea. In addition to them 8,995 servicemen of the Crimean Tatar nationality demobilized from the Soviet army were sent to special settlements. A significant number of deportees died at the resettlement places: the percentage of deaths among deportees was $19.6 \%^{10}$.

Before the annexation of the Crimea, Crimean Tatars were traditionally gathering on May 18th for a mourning rally in the center of Simferopol at the Lenin Square near the Council of Ministers of the Autonomous Republic of Crimea. However, immediately after the annexation, the occupant authorities banned Crimean Tatars from conducting a mourning action in the center of the Crimean capital in May 2014. For this purpose, the acting head of the occupant Council of Ministers of the Crimea, Serhii Aksionov signed an order prohibiting mass public gatherings in the Crimea by June 6 in connection with the "tense situation in the east of Ukraine."

The Chairman of the Republican Committee of Nationalities Zaur Smirnov explained the prohibition of the rally in the center of the Crimean capital by security concerns. "While we are not sure about the general security in the Crimea, there will be no mass events on Crimean Tatar subjects in the near future," he said at then ${ }^{11}$.

The Crimean Tatars were still allowed to hold a rally to the 70th anniversary of deportation, but on the outskirts of Simferopol and under close police supervision. The territory was surrounded by security forces,

9 Довідка про операцію по виселенню з Криму осіб татарської національності, підготовлена в Управлінні МВС по Кримській області. 12 серпня 1956 р. Крим в умовах суспільно-політичних трансформацій (1940-2015): Збірка документів та матеріалів: за ред. В. А. Смолія. Київ: Кліо, 2016. C. 71.

${ }_{10}$ Головченко В. Депортація кримськотатарського народу 1944 р. - прояв злочинності сутності національної політики сталінізму. URL: http://www.memory.gov.ua/publication/deportatsiyakrimskotatarskogo-narodu-1944-rproyav-zlochinnoi-sutnosti-natsionalnoi-pol

${ }^{11}$ Герасименко О., Галустян А. Что будет с крымскими татарами при российской власти. Власть. 22 сентября 2014. С. 12. 
police vans were standing nearby, and helicopters were circling in the air. "People perceive it as follows, "We were forbidden even to cry." It [the rally] was initially forbidden, then we were sent to the cemetery, and finally it was allowed to hold it, but outside of the city. And the whole entourage: police vans, paramilitary, soldiers, helicopters, snipers on the roofs created such a feeling that you are either in a reserve, or in a concentration camp", Crimean Tatar journalist Lilia Budzurova wrote.

Since that time any mass public events on the Day of Sorrow of the Crimean Tatar people are no longer held in Crimea. In 2015, the Crimean authorities refused to conduct a mournful action in Simferopol. In some districts of Crimea local Mejlises (the Crimean Tatar Parliament) held small rallies, the organizers of which later received fines from the occupant courts ${ }^{12}$.

The administrative protocols and fines were received by eight participants of the rally under the Crimean Tatar flags on May 18, 2015 ${ }^{13}$. In 2016, some local Mejlises submitted applications for mourning rallies and received a refusal from the local authorities.

Since 2015, the occupation authorities have decided to take control of the Mourning Day of the Crimean Tatar people. On May 18, 2015, the prime minister of the Crimean occupation government, Serhii Aksionov, together with other officials, put flowers to the memorials of deportation.

In 2016, the laying of flowers by the Crimea's officials was accompanied by the opening of the first part of a memorial to the victims of the deportation at the Syren station in the Bakhchysarai district. According to the plans of the occupant authorities, the memorial will include the historical museum of deportation, a mosque and a church. In this way the Russian authorities of the Crimea emphasize that not only the Crimean Tatars were deported from the Crimea. "Everything should be immortalized in order to allow people to come and remember the events of deportation, precisely at the place where people were deported from Crimea. This day should unite the Crimeans and demonstrate our unity," Aksionov said at the opening of the memorial ${ }^{14}$.

\footnotetext{
${ }^{12}$ Смедляев: главу регионального меджлиса в Крыму суд оштрафовал за митинг к годовщине депортации. Крым.Реалии. 26.06.2015. URL: http://ru.krymr.com/a/news/27094951.html

${ }^{13}$ Полиция задержала 60 участников автопробега в Симферополе. Крым.Реалии 18.05.2015 URL: http://ru.krymr.com/a/news/27022959.html

${ }_{14}$ Под Бахчисараем открыли первую очередь мемориала депортированным. РИА Крым. 18.05.2016. URL: http://crimea.ria.ru/society/20160518/1105062508.html
} 
Thus, following the annexation the Crimean Tatars were banned from holding traditional mournful public events throughout Crimea. Instead, the occupant authorities have imposed official events on the Crimean Tatars with the participation of Russian officials on the peninsula, during which the focus is on the tragedy of all deported peoples, and not just the Crimean Tatars.

\section{The Russian marking of the symbolic space of the Crimea as an instrument of the hybrid war}

A special place in the hybrid war is allocated to the symbolic space that the aggressor state can actively use for its political ends. According to M. Hon, a symbolic space is a reflection of the collective memory that is formed by and is a product of the actions in the political sphere. Monuments are the tools of this policy; they "emit" those semantic impulses that promote self-identification of citizens on the basis of new values and rethinking of the past ${ }^{15}$. That is why Russia pays special attention to the annexation of the symbolic space of the Crimea and by using monuments it attempts to consolidate "the native Russian status of the peninsula" in the minds of the Crimeans.

Symbolic space is not created by itself, but is the result of a certain policy. Under normal circumstances, the cultural symbolism of a city or region is created, to a greater extent, by the local political elite. In the case of the Crimea, the symbolic space is filled with the codes of memory by the invading state, who has annexed this space and created the conditions for the formation of the corresponding collective memory. Russian monuments are instrumental in this annexation of the symbolic space of the Crimea.

The main features of the modern marking of the symbolic space in the Crimea by Russia is the implementation of its new ideological paradigm - the combination of imperial and Soviet principles with an emphasis on a militaristic format. Therefore, several new monuments to Russian emperors quickly appeared in the Crimea, among which the first place belongs to Catherine the Second, during the rule of which the Crimea was annexed for the first time.

15 Гон М., Долганов П., Івчик Н. Місто пам'яті - місто забуття: палімпсести меморіального ландшафту Рівного: монографія. Рівне: Волин. обереги, 2017. С. 15. 
It is important to note that the first monument to the Empress appeared in the Crimea before the annexation of 2014. It was installed in June 2008 in Sevastopol to commemorate the 225th anniversary of the city's founding. The initiative to establish a monument belongs to the Veterans' Council of Sevastopol, who has begun the campaign to install the monument since the late 1990's. The struggle between pro-Russian activists and local authorities lasted for more than 10 years. In 2005, the local administration granted permission to install the monument for the first time, but due to litigation it was forced to confirm its decision two more times already in 2008, when the monument has already appeared in Sevastopol. Thus, the pro-Russian forces of the city were able to establish a marker of the Russian imperial tradition by installing the monument of Catherine the Second in the city center.

In Simferopol, the idea of installing the monument to Catherine the Great was related to "restoration of historical justice" - the monument to the queen already stood in the city center during pre-revolutionary times, but in 1921 it was dismantled. Attempts to revive the monument in the center of Simferopol started in the 1990's, but they were hindered by opposition from the Crimean Tatars. However, after the annexation, all obstacles disappeared.

In March 2015, the organization "The Russian Unity", headed by the wife of the head of the occupant Crimean government O. Aksionov, had initiated the restoration of the "historical monument", while the Russian Foundation of St. Basil Great had begun to raise funds. Over the course of several months, 46 million rubles were collected, and in the summer of 2016 the monument to Catherine was opened in the center of the Crimean capital.

The new monument was created by Moscow sculptors K. Kubyshkin and I. Iavorsky based on pre-revolutionary photographs in less than six months. The bronze statue of Catherine the Second takes the centre of the composition, and the sides of the monument are accompanied by the busts and statues of those whose names are associated with the first annexation of the Crimea - V. Dolgorukov-Krymsky, G. Potiomkin, O. Suvorov and Y. Bulgakov.

The next imperial monument appeared in the Crimea in the fall of 2017 - it is a monument to Alexander III in Livadia, which was opened 
personally by Russian President Vladimir Putin. "Alexander III loved Russia and believed in it, and, by opening this monument today, we pay tribute to his affairs, achievements and merits, express our respect for the continuous history of our country," V. Putin said ${ }^{16}$.

The memorial includes a monument to the emperor who sits on a stone, relying on a saber, and a stele behind his back demonstrating the achievements of the Alexander III era: from warships, cannons and rifles of Mosin to the Cathedral of Christ the Savior.

According to the plan of the author, the sculptor A. Kovalchuk, the emperor's uniform, the saber and his gaze at the Black Sea symbolize the end of the Russian-Turkish war of the1877-1878. The crown of the militarist style of the monument is the carved phrase, which is attributed to the emperor, "Russia has only two allies - its army and navy." Obviously, the view of the Black Sea symbolizes the ancient Russian dream of controlling the Straits of the Bosporus and Dardanelles, and the Crimea is an important springboard for the implementation of this plan.

The second direction of Russia's modern policy of memory is "the glorification of the Great Victory" in the Second World War. The Soviet myth of the Great Victory was reflected, firstly, by a monument devoted to the Yalta Conference of 1945, which was installed in February 2015 in Livadia.

The composition is represented by bronze sculptures of the three leaders of the winning states in the Second World War - F. Roosevelt, W. Churchill and J. Stalin. The monument was created by the Russian sculptor Z. Tsereteli in 2005 to commemorate the 60th anniversary of the Yalta conference. However, the attempts to install it failed due to strong opposition by the Ukrainian and Crimean Tatar communities. The protests of the local prosecutor's office forced the local authorities of Livadia to cancel the decision to erect this monument.

After the annexation of the Crimea there were no obstacles left for Russians, and the monument was solemnly opened marking the $70^{\text {th }}$ anniversary of the Yalta Conference. The installation of this monument triggered sharp criticism from the Crimean Tatars, who were deported from the Crimea in May 1944 by the order of the Soviet leader.

\footnotetext{
${ }^{16}$ Открытие памятника Александру III. URL: http://kremlin.ru/events/president/news/56125
} 
"The attitude of the Crimean Tatars to Stalin is well known. If the monument is still installed there will be a public demonstration of our position regarding the memory of Crimea and our people. The authorities should understand that they are directly responsible for the consequences of establishing this monument. This is a blasphemy", the member of the Mejlis of the Crimean Tatar people A. Egiz wrote regarding the monument ${ }^{17}$.

A memorial to the victims of a Fascist concentration camp was another major project of the occupant authorities on the peninsula. It was installed on the territory of the "Krasny" state farm in the village of Myrne near Simferopol, where 8 to 15 thousand people were killed according to various estimates.

The idea of its construction appeared even before the annexation. The decision to mark the territory of the former concentration camp as a historical monument of local significance was approved by the Verkhovna Rada of the Autonomous Republic of Crimea on May 18, 2011. ${ }^{18}$

In fall of 2012 deputies of the Verkhovna Rada of the ARC decided to create a memorial complex on this territory. In 2013 they promised to allocate 150 thousand UAH from extrabudgetary sources to establish this monument.

First of all, the memorial was solemnly opened on May 8, 2015, on the eve of the 70th anniversary of the Great Victory. Then the main works were completed: a museum of memory of prisoners and a chapel were built, as well as an eternal fire, a memorial bell, memorabilia on the places of the "wells of death" and a bronze figure of a girl were installed as a monument to the children who were killed in the camp.

The erection of this memorial has not so much historical, as the political context, because the Russians emphasize the fact that this "death camp" was precisely guarded by the battalion No. 152 "Shuma" formed from local Muslims (Crimean Tatars). According to the Crimean historian

\footnotetext{
17 Абдураман Эгиз: Установление памятника Сталину - кощунство. Меджлис крымскотатарского народа. Официальный сайт. URL:

http://qtmm.org/новости/4591-абдураман-эгиз-установлениепамятника-сталину-кощунство.

18 Постановление ВР АРК “Об объявлении территории бывшего фашистского концлагеря, располагавшегося в годы Великой Отечественной войны на землях совхоза "Красный”, историческим памятником местного (Автономной Республики Крым) значения “Концлагерь “Красный”. Портал Государственного Совета Республики Крым. URL: http://crimea.gov.ru/act/10101
} 
O. Romanko, with the advent of this battalion "the ordinary concentration camp turns into an extermination camp." 19

Obviously, such statements fully correspond to the Russian theory of justification for the deportation of the Crimean Tatars as a punishment for cooperation. According to the Crimean Tatar historian G. Bekirova, collaborators were among representatives of other peoples of the peninsula too. But "the facts of collaboration can not be a justification of the criminal decisions of the Soviet leadership about the deportation of entire peoples, implementation of which has brought countless tragedies to millions of innocent people" 20 .

On the other hand, the occupant authorities constantly emphasize that not only Crimean Tatars were deported but also other peoples of the peninsula - Greeks, Bulgarians, Armenians, etc., with a total of 37,000 people $^{21}$.

Considering the deportation as a policy aimed at the forced eviction of non-Slavic peoples from the Crimea, Russia is trying to deemphasize the crime of Soviet power against the Crimean Tatar people. This is exactly what the decree of the Russian President of April 21, 2014 is about; it is aimed at implementing measures for the rehabilitation of all deportees from Crimea - Armenian, Bulgarian, Greek, Crimean Tatar and German peoples.

Within the framework of this policy, a memorial is being erected for the victims of deportation in the Bakhchysarai district near the "Syren" station, where the deportation of the Crimean Tatars began. "Everything should be immortalized in order to allow people to come and remember the events of deportation, precisely at the place where people were deported from Crimea", the head of the occupant government of Crimea $\mathrm{S}$. Aksionov says revealing the meaning of Russian memorial policy regarding the deportations of $1944^{22}$.

19 Романько О. В. Немецкая оккупационная политика на территории Крыма и национальный вопрос (1941-1944): монография. Симферополь: Антиква, 2009. С. 161.

20 Бекирова Г. Крымскотатарская проблема в СССР (1944-1991). Симферополь: Оджакъ, 2004. C. 21.

21 Зарубин В. Г. Депортация из Крыма армян, болгар, греков и представителей других этносов (1944г.). Проблеми інтеграції кримських репатріантів в украйнське суспільство. Матеріали Всеукраїнської науково-практичної конференції, м. Київ, 13-14 травня 2004 р.

К.: Світогляд, 2004. С. 181-191.

${ }_{22}$ Под Бахчисараем открыли первую очередь мемориала депортированным. РИА Новости. 18.05.2016. URL: https://crimea.ria.ru/society/20160518/1105062508.html 
The third direction of marking the Crimean symbolic landscape is related to the military codes that appear on other monuments (Emperor Alexander III), as well as represented by personal monuments in honor of the military.

In June 2016, in Simferopol, a monument to the "Little Green Men" was opened commemorating the Russian special forces who seized the Crimea in February - March 2014. The sculpture created by the Russian artist S. Shcherbakov is represented by three bronze characters: a bronze soldier, a girl with a bouquet of flowers and a cat that should symbolize the politeness of the Russian military and the "peaceful nature of the Crimea's accession".

A similar logic is represented in the monument of the People's militia of all time, which was established according to the project of a member of the Crimean "self-defense" paramilitary V. Kliuiev in Simferopol at the end of 2016. A monument of 11 meters in height and at a cost of 19.5 million Rubles combines the three waves of the "people's militia" the time of the Crimean War of 1853-1856, the time of the Second World War and the period of the "Crimean Spring" of 2014, when the proRussian organizations of the peninsula created units of paramilitary "selfdefense" to "protect the Crimea from the Kyiv junta". With the help of this memorial, the Russian authorities of the peninsula are trying to prove that the Crimeans not only wanted to join Russia, but they were also prepared to "protect the Crimea with arms in their hands."

There were only a few Ukrainian symbols in the Crimea, but both monuments dedicated to the military history of Ukraine were taken from Crimea immediately after the annexation of the peninsula.

In April 2014, the Kremlin's appointee, the governor of Sevastopol Serhii Meniailo ordered to dismantle two monuments - a monument commemorating the 10th anniversary of the Naval Forces of Ukraine, and a monument to Hetman Sahaidachny. According to S. Meniailo, Sevastopol is a city of Russian sailors. "There were no other seamen in Sevastopol from time immemorial. Therefore, it is necessary to restore justice", he stressed. Although in fact, during the Crimean War, a third of the sailors of the Russian Black Sea Fleet were Ukrainians; they were 
recruited mainly from the population of the Tavria, Kherson and Yekaterinoslav provinces $^{23}$.

\section{CONCLUSIONS}

One of the main features of the hybrid war is that it is not for a territory, but for controlling the minds of people. This particular battle for the minds of the Crimeans, has been led by Russia since the collapse of the USSR through a variety of pro-Russian organizations that lobbied Russian symbols on the peninsula.

A large number of Russian-Soviet cultural symbols conditioned the domination of Russian-Soviet cultural identity, to which more than $70 \%$ of Crimeans indicated they belong. This fact greatly facilitated the occupation of the Ukrainian peninsula.

Following the annexation of the Crimea, Russia has implemented its historical policy on the state level by annexing the Crimean space of memory and consolidating Russian symbolism in the mass consciousness of the Crimean people. The peculiarity of the formation of collective memory in Crimea is that it is created in the context of modern Russian mythology, where the peninsula is given an important position - to demonstrate the indisputable Russian status of Crimea through historical ties.

New monuments to the Russian emperors symbolize the "joining" of the peninsula with the help of military force, as well as further use of it in the implementation of Russia's military plans. The militarization of the symbolic space of the Crimea is solidified in the modern monuments - the "people's militia", which combines imperial, Soviet and contemporary times, focusing on "people's struggle against the enemies" and the "little green men" as "polite Russian soldiers."

The deportation of the Crimean Tatars in Russia is attempted to be closely linked to the forced eviction of other peoples, creating in collective memory the notion of a general deportation of the non-Slavic population of the peninsula during the Stalin's times.

Some Ukrainian cultural codes have been dismantled, while others are attempted to be injected into the Russian memorial policy with the

\footnotetext{
${ }^{23}$ Громенко С. В. \#Кримнаш. Історія російського міфу. К., 2017. С. 76.
} 
help of the artificially created and controlled power of the Ukrainian community of Crimea.

Such memorial policy of Russia is aimed at the mental integration of the Crimea to the Russian cultural and symbolic space.

\section{SUMMARY}

This article analyzes the features of the cultural and symbolic space of the Crimea before and after the annexation of the peninsula by the Russian Federation. It is determined that the symbolic landscape of the Crimea is a Russian-Soviet heritage, which has predetermined the dominance of the Russian-Soviet cultural identity on the peninsula. It is proved that after the annexation, Russia has attempted to impose their own vision of history on its representatives of the Ukrainian and Crimean Tatar communities and creates a correspondent symbolic space behind it by installing new monuments of imperial and militaristic orientation.

\section{REFERENCES}

1. АР Крим: люди, проблеми, перспективи. Начіональна безпека та оборона. 2010. № 10. С. 3-72.

2. Бекирова Г. Крымскотатарская проблема в СССР (19441991). Симферополь: Оджакъ, 2004. 330 с.

3. Герасименко О., Галустян А. Что будет с крымскими татарами при российской власти. Власть. 22 сентября 2014. С. 10-22.

4. Головченко В. Депортація кримськотатарського народу 1944 p. - прояв злочинності сутності національної політики сталінізму. URL: http://www.memory.gov.ua/publication/deportatsiyakrimskotatarskogo-narodu-1944-rproyav-zlochinnoi-sutnostinatsionalnoi-pol

5. Гон М., Долганов П., Івчик Н. Місто пам'яті - місто забуття: палімпсести меморіального ландшафту Рівного: монографія. Рівне: Волин. обереги, 2017. 232 с.

6. Громенко С. В. \#Кримнаш. Історія російського міфу. К., 2017. 224 c.

7. Довідка про операцію по виселенню з Криму осіб татарської національності, підготовлена в Управлінні МВС по Кримській області. 12 серпня 1956 р. Крим в умовах суспільно-політичних 
трансформацій (1940-2015): Збірка документів та матеріалів : за ред. В. А. Смолія. Київ: Кліо, 2016. 1092 с.

8. Зарубин В. Г. Депортация из Крыма армян, болгар, греков и представителей других этносов (1944г.). Проблеми інтеграції кримських репатріантів в українське суспільство. Матеріали Всеукраїнської науково-практичної конференції, м. Київ, 13-14 травня 2004 р. К.: Світогляд, 2004. С. 181-191.

9. Романько О. В. Немецкая оккупационная политика на территории Крыма и национальный вопрос (1941-1944): монография. Симферополь: Антиква, 2009. 272 с.

10. Хриенко Т.В. Молодежь Крыма о полытике и политиках (опыт соцыологических исследований): монография. Симферополь, 2013. $132 \mathrm{c}$.

11. Hoffman F. G. Hybrid Warfare and Challenges. Joint Force Quartelly (JFQ). Issue 52. Forth Quarter. 2009. P. 34-39. 